\title{
3-2-3ＶTR 一体型ハーピコンカメラ
}

\author{
正会員 浮ケ谷 文 雄 $^{\dagger}$, 正員会 橘 川俊 哉 ${ }^{\dagger \dagger}$ \\ 正会員 高 崎 幸 男 ${ }^{\dagger+}$
}

\section{1. ま え がき}

超高感度, 高画質を実現したハーピコンカメラは, これまでのテレビカメラでは捉えることのできなかっ た撮影が可能であり, 現在, 舞台中継, ナイター中 継, 自然科学番組, 緊急報道等で幅広く活躍中であ る1)2).

しかし，現用中のハーピコンカメラはスタジオ型， ハンディ型であるため, Vロ文, 報道用としては, 小型・低消費電力化による一層の機動性向上が要望さ れていた。

そこで今回, この要望に応えて, 新たに小型・軽 量・低消量電力化設計を図り, 機動性に優れた VTR 一体型の運用が可能なハーピコンカメラを開発した. また, 運用の多目的化を図るため, マルチユース運用 ができる設計であり，VTRの代りにトライアックス （TRIAX）またはマルチコアアダプタを接続すること により CCUと接続することも可能であり, スタジ オ/中継用カメラシステムとして運用できる.

さらに，小型・軽量・低消費電力化したことにより リモコン雲台U-4(ロボットカメラ)にも組み込みが容 易となり, 制御用インタフェースも同時に開発した。 本稿では, ハーピコン®の原理と特長, カメラとして ハーピコンの電子冷却技術, 小型・軽量・低消費電力 化, 機能/操作性について述べた後, 運用形態および 実施例について報告する。

\footnotetext{
(B) 登録商標

$\dagger$ 日立電子株式会社 映像事業部

故 NHK 技術局

†† 日立製作所 茂原工場

"3-2-3 Dockable HARPICON Color Camara" by Fumio Ukigaya (Broadcast and Video Products Div., Hitachi Denshi, Ltd., Tokyo), Toshiya Kikkawa (Engineering Administration Dept., NHK, Tokyo) and Yukio Takasaki (Mobara Works, Hitachi, Ltd., Chiba)
}

\section{2. 撮像管ハーピコン}

図 1 に今回開発したカメラに搭載している対サチコ ン®比最大 32 倍感度ハーピコンの代表的な電圧・電流 特性を示す3) 5). 光電流はターゲット電圧の増加とと もに上昇し，いったん飽和傾向を示したあと再び大き く増加する．この領域がハーピコンの動作するアバラ ンシェ倍増領域であり，かつ暗電流は充分抑制された 電圧に設定される。例えば 32 倍感度動作の場合, そ の電圧は約 $460 \mathrm{~V}$ となる.

この電圧は, 電界強度にすると約 $10^{8} \mathrm{~V} / \mathrm{m}$ と従来の 撮像管に比べ約 1 桁高い電界であり，そのため光導電 膜の下地や内部のサブミクロンの欠陥や異物が原因と なり, 画面欠陥を生ずる可能性が高い. 上記の 32 倍 感度ハーピコンでは, ガラス基板の平滑化, 高品位透 明電極形成法等, 従来のハーピコンターゲット形成技 術のレベルアップ, また光導電膜仕様の改良によって この問題を解決した.

現在, 研究所を中心にハーピコンのさらなる高感度 化の検討が進められており, 従来にない高画質で高感

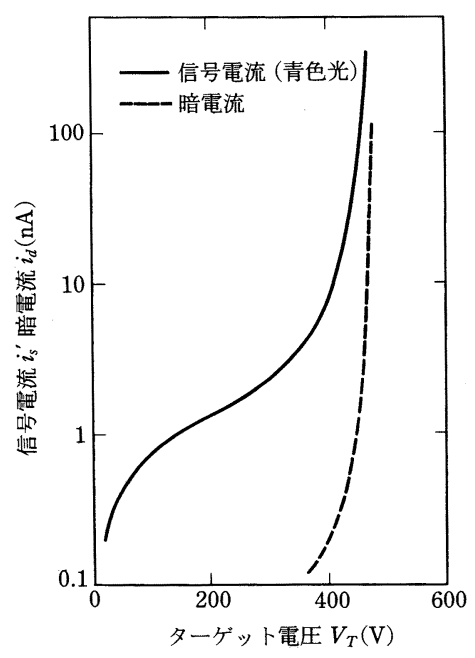

図 1 ハーピコンの電流-電圧特性

テレビジョン学会誌 Vol. 46, No. 4, pp. 466〜469 (1992) 
度を達成したハーピコンの今後の展開が期待される．

\section{3. カ メ ラ}

\section{1 電子冷却}

ハーピコンはアモルファスセレンを主成分とした光 導電膜を使用しているので, 長時間にわたり高温下で 使用すると劣化する，そこで，本カメラではこの対策 として R, G, B 各チャンネルの撮像管膜面を冷却す るため各々にペルチェ素子を用いて電子冷却してい $ろ^{6)}$.

冷却プロセスはペルチェ素子をターゲット近傍に装 着し, 吸熱して光学系ブロックを通してカメラ筐体よ り外部に放熱する。

また, ターゲット近傍に温度センターが設けられ電 子冷却の温度制御を行い, 膜面を適温に保っている。

図 2 に電子冷却の結果を示す. 図より, 電子冷却は 約 $20^{\circ} \mathrm{C}$ (膜面 $28^{\circ} \mathrm{C}$ ) より 動作し, 周囲温度上昇に比例 してペルチェ素子の電流が増加し, 周囲温度が $40^{\circ} \mathrm{C}$ でも約 $15^{\circ} \mathrm{C}$ 冷却し, ターゲット膜面温度は $35^{\circ} \mathrm{C}$ 以 下に保たれる。

\section{2 小型 $\cdot$ 軽量・低消費電力化}

今回の開発の重要テーマは, 報道取材カメラとして 小型・軽量・低消費電力化し VTR一体型カメラとす ることであった.

低消費電力化の手段としては, (1)回路の工夫とカス タイム IC 化, デバイスの選定等を徹底し, 回路電圧 を従来の $\pm 6 \mathrm{~V}$ から $+5 \mathrm{~V}$ 片電源化したこと, (2)無 効電力のないペルチェ素子駆動方式にしたこと, (3)高 能率のハーピコンターゲット高圧発生回路を採用した
こと，(4)高能率電源回路の追求等である。この結果， 表 1 に示すように, 従来カメラ $38 \mathrm{~W}$ に対し, $25 \mathrm{~W}$ と大幅な低消費電力化を実現できた。

一方, 小型・軽量化としては, カスタム IC 化, 高 安定化回路設計による補助機能の削除, 高密度実装技 術の駆使, 内部構造の徹底した簡素化, 無配線化等に より, 表 1 に示すように従来カメラ比 $1 / 2$ の大きさ, 重量 $5 \mathrm{~kg}$ とした.

開発したカメラの外観を写真 1 に示す.

\section{3 機能・性能}

一般的な基本機能は通常カメラと同じである. 感度 切換えは, いわゆるハイゲインに加え, ハーピコン特 有のターゲット電圧を変えることによる感度切換えが

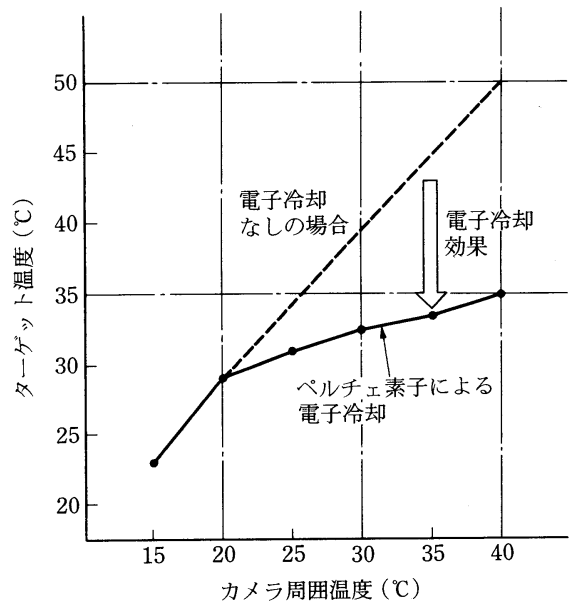

図 2 電子冷却によるハーピコンターゲット温度

表 1 主要諸元

\begin{tabular}{|c|c|c|}
\hline 諸 元 名 & $\begin{array}{c}\text { VTR-体型 (新型) } \\
\text { SK-H } 5 \\
\text { (日立電子) }\end{array}$ & $\begin{array}{l}\text { ハンディ型(現用) } \\
\text { SK-97 HS (-H 50) } \\
\text { (日立電子) }\end{array}$ \\
\hline $\begin{array}{c}\text { 感 度(倍) } \\
\text { （対サチコン比） }\end{array}$ & $\times 30\left(\begin{array}{l}\mathrm{NHK} \\
\times 60\end{array}\right)$ & $\times 10, \times 30\left(\begin{array}{ll}\mathrm{NHK} \\
\times 60, & \times 100\end{array}\right)$ \\
\hline 解像度 (TV 本) & 700 & 700 \\
\hline$S / N(\mathrm{~dB})$ & 58 & 57 \\
\hline 重 量(kg) & 5 & 8.4 \\
\hline 消費電力 (W) & 25 & 38 \\
\hline $\begin{array}{c}\text { 寸法形状 } \\
\mathrm{W} \times \mathrm{H} \times \mathrm{D}(\mathrm{mm}) \\
(\text { 容積 })\end{array}$ & $\begin{array}{c}110 \times 265 \times 210 \\
(6 l)\end{array}$ & $\begin{array}{l}116 \times 305 \times 355 \\
\quad(12.6 l)\end{array}$ \\
\hline システム対応 & $\begin{array}{l}\text { 1. } \beta \text {-CAM一体型 } \\
\text { 2. トライアックス }(\mathrm{R} / \mathrm{G} / \mathrm{B}) \\
\text { 3. 多心ケーブル }\end{array}$ & 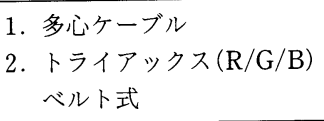 \\
\hline
\end{tabular}




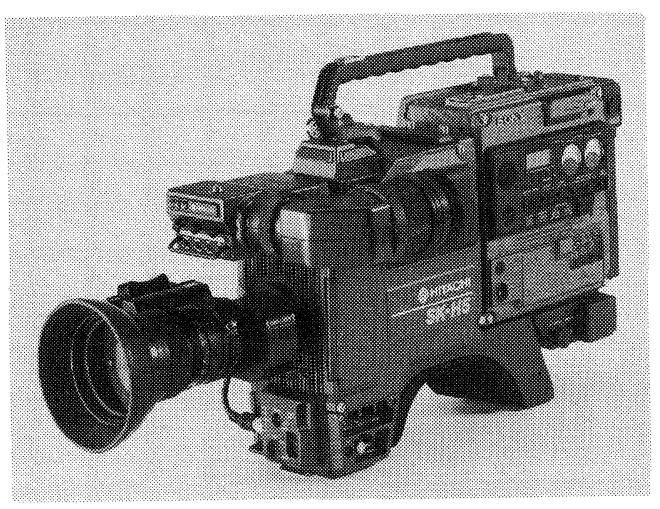

写真 1 VTR一体型ハーピコンカメラ SK-H 5

ある。

開発したカメラでは, 30 倍感度ハーピコンの場合, $8,16,20,30$ 倍の 4 ステップ切換モードを持ってい る. 八イゲインと異なり, 感度を切換えても黒の $S / N$ は劣化しない特長がある.しかも, 光入射時のショッ トノイズによる $S / N$ 劣化も他の高感度カメラに比心゙ 少なく優れている.

また, 高圧回路は, 将来の 100 倍感度管まで実装で きるように準備されている。

性能面では, 表 1 に示すように, $S / N$, 解像度共 に標準カメラ並の優れた特性を持っており, 残像も 30 倍管の場合, プランビコン®と同等である。また， 色再現性は新設計のプリズム分光性により標準カメラ のプランビコン色に合わせた．さらに，ハーピコンの 大きな特長として, 撮像管自体がハイライト光でニー 特性を持つことである。この特性により広ダイナミッ クレンジの撮像が可能となり, 従来のニー回路とは一 味違う, よりリアルな画像表現ができる.

したがって, ハーピコンカメラは, いわゆる高感度 特殊カメラとしてだけでなく, 標準撮像カメラから高 感度カメラまで幅広く使える, コスト/パフォーマン スの良いカメラである。

\section{4. 運 用 形 態}

\section{1 各種運用形態}

図 3 に,ハーピコンカメラ SK-H 5 の運用形態を 示す.

(1) VTR一体型

従来のハーピコンカメラ SK-97 HS（または-H 50) はハンディタイプで, ENG/EFPには 26 ピン標準イ ンタフェースによりポータブル VTR と接続するしか なかったが, SK-H 5 では小型・軽量化を図り, ベー タカム標準 50 ピンインタフェースにより, 一体型

-VTR一体型

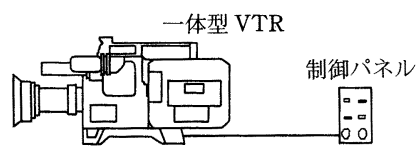

·TRIAX システム

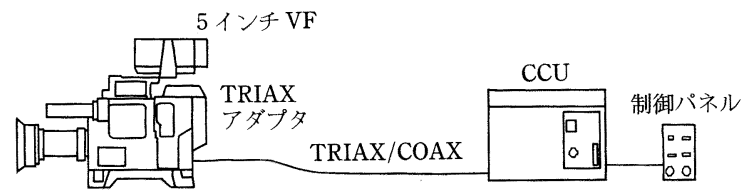

-U-4 システム

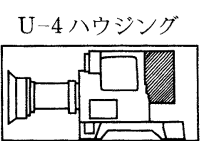

18 倍レンズ
$\mathrm{U}-4$ アダプタ

図 3 SK-H 5 の運用形態

VTR との結合が可能である.これにより機動性が大 幅に向上し, Vロケ・緊急報道に扔ける運用が容易に なった。

(2) TRIAX システム

一体 VTR の代わりに TRIAX アダプタを接続する ことにより，CCUによる制御が可能である. 劇場中 継, 高倍率レンズを使用したスポーツ中継等でのマル チカメラ運用にも対応できる。

コンサートやゴルフ中継等でハンディカメラとして 使用する場合，カメラヘッドにバッテリーで電源を供 給しておけば，同軸ケーブルの差し換えのみで簡単に ポジションチェンジを行うなどの運用も可能である.

制御パネルは，VTR一体型運用時のリモコンパネ ルおよび TRIAX システム構成時は CCU のオペレー ションパネルとして使用できる．新しい機能としては 感度切換えのリモート制御があり，4 ステップの切換 えが可能である.

（3）リモコンカメラシステム U-4 との結合

SK-H 5 ではカメラヘッド部で $25 \mathrm{~W}$ と低消費電力 化されているので，U-4 (キヤノン製) に組込むことが 可能である. NHK では, 雲仙普賢岳監視用にこのシ ステムを利用している（写真 2).

U-4アダプタは，U-4 操作パネルからのカメラ制 御信号を SK-H 5 のシリアル制御信号にプロトコル 変換するために必要なアダプタである。

\section{2 ハーピコンカメラの位置づけ}

図 $4^{1)}$ に標準感度の CCD カラと高感度カメラの使 用区分を示す。 


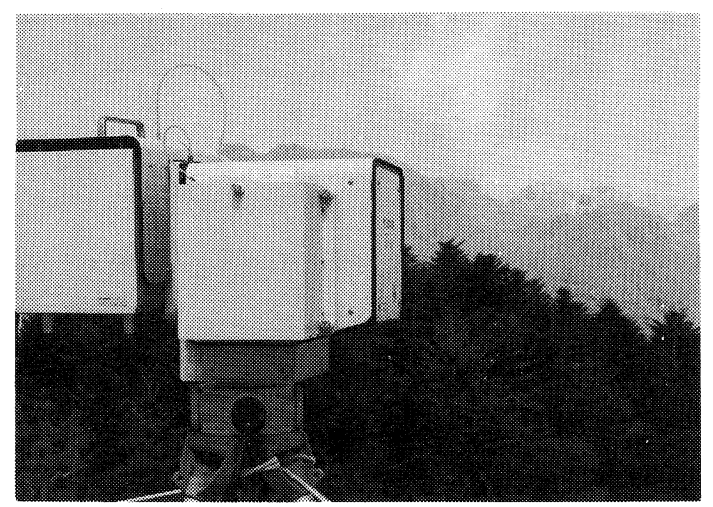

写真 2 雲仙普賢岳監視用ハーピコンカメラシステム

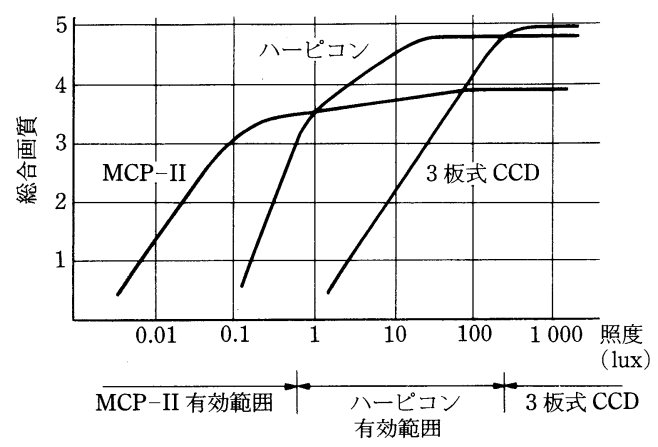

図 4 カメラ使用区分

微弱光での撮影は $S / N$, 解像度を犠牲にしても絶 対感度の高い MCP-II, 充分な照明が可能な条件下で は運用性, 八イライト特性の面で通常の 3 板式 CCD カメラ等が有効であるが，それ以外の照明条件下では 高 $S / N$, 高感度のハーピコンカメラが効果的であ る。

\section{5. む す び}

ハーピコンカメラは，これまでのカメラでは撮れな かった新しい映像作りの道具としてNHKはじめ各
局で幅広く運用されて, 早や 2 年半経過した。この運 用経験から，さらに使い勝手の良いVTR一体型カメ ラが各局より強く要望され，第 2 弾として，本カメラ が新たに開発され，すでにNHK 他に導入され活躍 中である。また，ハーピコンのさらなる高感度化の研 究開発も進められており, 今後への期待の持てるカメ ラである。

最後に, 本カメラの開発にあたり, 御指導御鞭撻を 賜りました NHK，日立製作所他，関係各位に深く感 謝致します。

(1991 年 12 月 26 日受付)

\section{〔参 考 文 献〕}

1）今野：“最近の高感度カメラを用いた番組制作”, テレビ学 技報, 14，27，pp. 31-35（May 1990）

2）今野, 和田ほか：“スーパーハープ管カメラの実際”, クロ マ (May 1991)

3）谷岡, 山崎ほか： “アバランシェ増倍 $\mathrm{a}-\mathrm{Se}$ の光導電膜を用 いた高感度 HARP 撮像管”, テレビ誌, 44, 8, pp. 116125 (1990)

4）竹歳, 谷岡ほか：“高感度ターゲットにおける SN 比の考 察”，テレビ学技報， $10 ， 45$, pp. 7-12（Jan. 1987）

5）後藤, 辻ほか：“アバランシェ動作型撮像管ハーピコンの動 作解析”，テレビ全大，3-13（1990）

6）吉田, 浮ケ谷ほか：“超高感度ハーピコンカラーカメラ”, テレビ学技報，14，66, pp. 21-26（Nov. 1990）

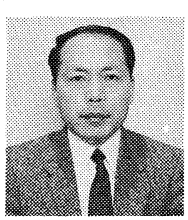

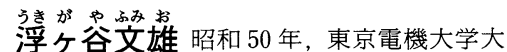
学院博士課程修了. 同年, 日立電子 (株) に入 社. 回路設計用 CAD の研究, 放送用カラー カメラの開発・設計に従事. 現在, 同社映像 事業部放送設計部副部長. 工学博士. 正会 員.

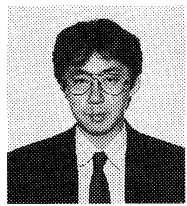

橘川倒哉 昭和 59 年, 早稲田大学大学 院修士課程修了。同年, NHK に入局. 高松 放送局を経て, 62 年より, 同放送技術研究 所にて,プラズマディスプレイの研究に従 事. 平成 2 年より, 同技術局にて放送機器の 開発に従事．現在に至る。正会員．

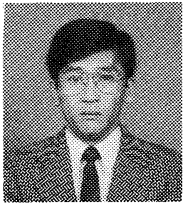

驾崎等势 昭和 50 年, 横浜国立大学大 学院工学研究科電気工学専攻修士課程修了. 同年，(株) 日立製作所中央研究所に入社. 以 来，非晶質半導体の物性および撮像デバイス への応用研究に従事. 平成元年, 同社茂原工 場に移り, 現在, 同工場主任技師. 正会員. 